\title{
First Report of Dermestes frischii Kugelann (Coleoptera: Dermestidae) on a Human Corpse, South of Iran
}

\author{
Keshavarzi $\mathrm{D}^{1}$, Moemenbellah-Fard $\mathrm{MD}^{1 *}$, Fereidooni $\mathrm{M}^{2}$, Montazeri $\mathrm{M}^{2}$
}

${ }^{1}$ Department of Medical Entomology and Vector Control, Research Centre for Health Sciences, School of Health, Shiraz University of Medical Sciences, Shiraz, Iran.

${ }^{2}$ Shiraz Institute of Legal Medicine, Shiraz, Iran.

\begin{abstract}
The necrophagous species of beetles provide useful complementary data to estimate the post-mortem interval in forensic cases. We report, for the first time, Dermestes frischii Kugelann, 1792 larvae from a mummified human body covered with bushes and located in a canal in Sarvestan district, Fars province, south of Iran. The human corpse was a 63 year old male. The time of death was estimated to have been 23 days prior to the finding of the body based on the police investigations and confessions of a suspect. This beetle can be helpful to estimate the time of death in the future.
\end{abstract}

Keywords: Beetles (Coleoptera); Dermestes Frischii; Forensic Entomology; Human Cadaver.

\section{*Corresponding Author:}

Dr. Mohammad Djaefar Moemenbellah-Fard,

Associate professor, Department of Medical Entomology and Vector Control, Research Centre for Health Sciences, School of Health, Shiraz University of Medical Sciences, P.O. Box 71645-111, Shiraz, Iran.

Tel: 0098-713-7251001-8

Fax: 0098-713-7260225

E-mail: momenbf@sums.ac.ir momenbf@yahoo.com

Received: February 26, 2015

Accepted: April 27, 2015

Published: April 30, 2015

Citation: Keshavarzi D, Moemenbellah-Fard MD, Fereidooni M, Montazeri M (2015) First Report of Dermestes frischii Kugelann (Coleoptera: Dermestidae) on a Human Corpse, South of Iran. Int J Forensic Sci Pathol. 3(4), 113-115. doi: http://dx.doi.org/10.19070/2332-287X-1500027

Copyright: Moemenbellah-Fard MD ${ }^{\odot}$ 2015. This is an open-access article distributed under the terms of the Creative Commons Attribution License, which permits unrestricted use, distribution and reproduction in any medium, provided the original author and source are credited.

\section{Introduction}

The study of beetles (Coleoptera) is important in forensic investigations. This can be helpful in determining the time of death or postmortem interval (PMI) [1]. Insects colonize the corpse in a predictable regularity; and beetles are found in the late stage of body decomposition [2]. Decomposition stages in an open environment are different from those in a closed environment, as closed environment may act as a barrier to insect species that are important in forensic entomology [3].

Dermestid (or hide) beetles are a family of insects in the order of Coleoptera. This order is distinct from others by the presence of a pair of hardened and thickened wings or "elytra". The key characteristics that differentiate this family from other families are clubbed antennae that fit into deep grooves and round oval shaped bodies covered in scales. Most genera of Dermestidae family are scavengers that feed on dried animal tissues or plants. In this family, Dermestes genus is important in forensic entomology and is active during the warmer months of the year $[2,3]$.

The Dermestes frischii which belongs to the Dermestes genus, is differentiated from other genera by the absence of a median ocellus on front head and the presence of a pair of compound eyes, hind wings and a scutellum. This species is black and oval shaped. The size of this species is $6-12 \mathrm{~mm}$ in length and $4-5 \mathrm{~mm}$ in width. The elytra is completely covered with pale scales $[4,5]$. This species is cosmopolitan in distribution and appears to be similar to Dermestes maculatus, but the apical part of the elytra has a specific spine in D. maculatus. Each abdominal sternite has 2 lateral black spots in adults. The sternite of the abdomen has a white pubescence.

The species of Dermestes ater can be separated from Dermestes frischii by the underside of the abdomen that is light brown with dark brown patches in the middle and on the sides in D. ater. The larvae are elongated, narrow and dark brown to black in color. Their size ranged from $5-15 \mathrm{~mm}$ in length. On the $9^{\text {th }}$ abdominal segment, there are two rigid sharp spikes called "urogomphi". The larvae of this species can be distinguished from other species by an equally wide light-color longitudinal dorsal stripe on the head, thorax and the abdomen and spiky ends of the urogomphs that are curved distinctly toward the insects' backs $[5,6]$. This species has been reported in various regions of the world on human and animal cadavers, as this species was reported on human corpses in France. D. frischii was dominant in this study [7]. This species was reported from animal carcasses in different regions $[8,9]$. In Iran, dermestid beetles have never been reported from any human corpses so far.

\section{Case Study}


A 63 years old man was found dead in the field, in Sarvestan district, Fars province $\left(29^{\prime} 20^{\circ} \mathrm{N}, 5^{\prime} 15^{\circ} \mathrm{E}\right)$ and taken to Shiraz Institute of Legal Medicine on $19^{\text {th }}$ September 2014. The cause of death was homicide. The time of death was estimated to have been 23 days before the discovery of the body based on the police investigations. The victim was strangled in the trunk of a car and then transferred to a channel to hide instantly. Part of the body that was in indirect contact with sunlight was hard, stiff and leathery. The head of the corpse was completely skeletonized exposing the skull and the lower jaw was broken. Beetles' larvae were collected from the corpse during autopsy procedures by the first author at $8.45 \mathrm{am}$. Some five beetles' larvae were collected from the face and transferred to the laboratory of Entomology for rearing. It should be noted that in this case, we did not find any adult fly on the corpse.

The live larvae were reared on chicken meat and they were kept in a separate container and placed in a dark place. The temperature of the rearing room was $28 \pm 1^{\circ} \mathrm{C}$ and monitored daily. The mean length of the beetle larvae were $11 \pm 2 \mathrm{~mm}$. The body color was dark brown and have a hairy appearance (Figure 1). The growth time of the larvae to become pupae was 9.5 days and the time of pupation to adult emergence was 8 days. The emerged beetles were then killed and identified by using valid taxonomic keys [10, 11] and compared with the valid pictures [12].

The Dermestes frischii adult can be distinguished from other species in Dermestidae family by the small black spots at each side on the sternite; also the last sternite has a median blackish spot on its rear border, which does not extend to the front border of the sternite $[5,6]$. The confirmation of this species was done based on its habitus and the abdomen of the adult (Figures 2 and 3) by Andreas Herrmann, a leading expert on Dermestidae beetles.

\section{Discussion}

The presence of this species larva and adult is varied with the decomposition stage of the corpse or carcass. The Dermestes genus larvae were found on a human corpse in the early stages of advanced decay (day 21) [13]. The Dermestes frischii adults are reported on human leftover parts at all decomposition stages (fresh, bloat and dry stage), but larval first appearance was in the decay stage of body decomposition (day 9) [4]. This species was collected in the active decay stage (days 2-8), advanced decay (days 8-13) and dry stage (days 13-21) in summer [8]. Study on pig carcasses showed that Dermestes frischii was seen in the advanced decay and dry stages of decomposition [14]. Other species of Dermestes genus associated with corpses were found in many parts of the world, as Dermestes ater larvae were first found on a dead human body 14 days after death in Malaysia [15]. Dermestes maculatus and Dermestes ater (adults) were recorded on animal cadavers in the stages of a bloat (day 4) and decay (day 15) [16]. Dermestes maculates adult was found on a pig carrion in the advanced decay stage (4-6 days) in Thailand [17]. Other life stages of Dermestid beetles such as pupa and exuviae may be collected from the human corpse in late stage of body decomposition and serve as reliable alternate specimens for toxicological analyses in the absence of tissues and fluids normally, for example; Amitriptyline and Nortriptyline drugs isolated from Dermestidae exuviae in a mummified human

Figure 1. The habitus of Dermetes frischiilarva with a hairy body.

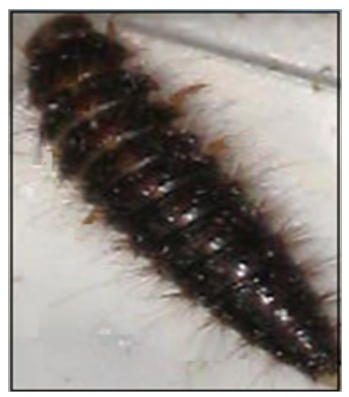

Figure 2. The habitus of Dermetes frischii adult with a pair of elytra.

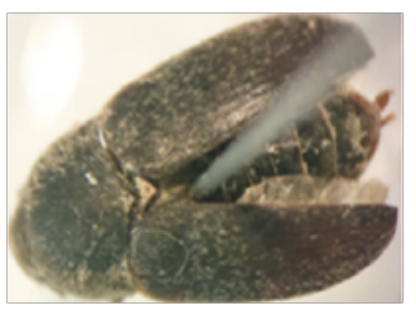

Figure 3. Ventral view of Dermestes frischii adult showing the apical abdominal sternite with black pubescence at apex.

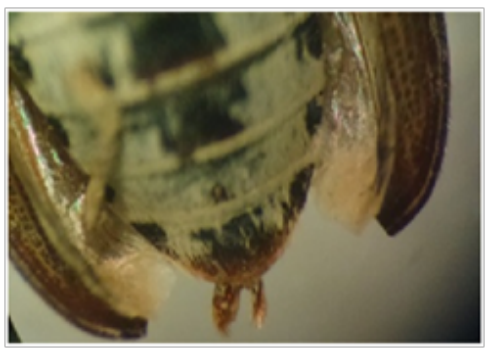


remains [18].

This difference between previous reports could emanate from the geographical and climatic differences because the decomposition process is different in each region [19]. Therefore, our report indicates the presence of larvae in the stage of advanced decay, when the tissues are suitable for feeding larvae. The aim of this study was not to estimate the PMI for a corpse, because in our study the maximum postmortem interval of 23 days was indicated by confessions of a murderer. The goal of this study was to document a beetle species associated with the human corpse in Iran, where many infectious and non-infectious diseases also prevail.

For estimation of post-mortem interval using this beetle larvae in Iran, it is important to study the rates of development in this species because the rates of development for Dermestes frischii and other species of the Dermestidae family is different in different strains and different foodstuffs $[20,21]$. Forensic entomology is a neglected field in Iran and in order to make baseline studies, more research is needed. Eventually, we hope to advance forensic entomology in Iran.

\section{Acknowledgement}

This paper has been extracted from parts of Keshavarzi, D. MSc thesis supported by the Research Council of Shiraz University of Medical Sciences (Thesis Cod: 93-7295). We would like to thank Andreas Herrmann for his time and help in the species identification. The authors are grateful to the Shiraz Institute of Legal Medicine.

\section{References}

[1]. Catts EP, Goff ML (1992) "Forensic entomology in criminal investigations." Annual Review of Entomology 37: 253-272.

[2]. Gennard DE (2007) Forensic Entomology- An Introduction. John Wiley\& Sons Ltd: England.

[3]. Byrd JH, Castner JL (2009) Forensic Entomology: The Utility of Arthropods in Legal Investigations, Boca Raton: CRC Press.

[4]. Yones DA, Attia RA, Galal LA, Hameed SY (2010) "Identification of forensically important beetles on exposed human leftover parts in Assuit, Egypt during spring/summer". Assiut Medical Journal 34: 123-130.

[5]. Fohrer F, Rasplus J, Martinez M (2014) Insects known to cause damage to heritage works. http://www1.montpellier.inra.fr

[6]. Green AA (1967) "The protection of dried sea-fish in South Arabia from infestation by Dermestes frischii Kug. (Coleoptera, Dermestidae)". Journal of Stored Products Research 2(4): 331-350.

[7]. Charabidze D, Colar T, Vincent B, Pasquerault T, Hedouin V (2014) "Involvement of larder beetles (Coleoptera: Dermestidae) on human cadavers: a review of 81 forensic cases". International Journal of Legal Medicine 128(6): 1021-1030.

[8]. Kökdener M, Polat E (2014) "Insect succession on dog (Canis lupus familiaris L.) carcasses in Samsun province, Turkey". Munis Entomology \& Zoology 9(2): 858-869.

[9]. Özdemir S, Sert O (2009) "Determination of Coleoptera fauna on carcasses in Ankara Provinc, Turkey". Forensic Science International 183(1): 24-32.

[10]. Arnett RH, Downie NM, Jagues HE (1980) "How to know the beetles". (3rd Edtn). Brown Company Publishers.

[11]. Hava J, Kadej M (2006) "New data on the occurrence of Dermestidae (Coleoptera) from Hispaniola. Part 1. Dermestes Genus". Polish Journal of Entomology 73(5): 375-377.

[12]. Herrmann A (2014) Interest: Dermestidae (Coleoptera) of the world, Bremervörder Straße 123, D -21682 Stade, Germany. http://www.dermestidae.com/

[13]. Anderson GS, Vanlaerhoven SL (1966) "Initial studies on insect succession on carrion in South Western British Columbia". Journal of Forensic Sciences 41(4): 617-625.

[14]. Bana R, \& Beyarsalan A (2012) "Determination of Coleoptera species of pig carcasses and internal organs of bovine in Edirne city of Turkey". Bitlis Eren Üniversitesi Fen Bilimleri Dergisi 1(2): 122-126.

[15]. Kumara TK, Abu Hassan A, Che Salmah MR, Bhupinder S (2006) "The infestation of Dermestes ater (De Geer) on a human corpse in Malaysia". Tropical Biomedicine 26(1): 9-73.

[16]. Voss SC, Forbes SL, Dadour IR (2008) "Decomposition and insect succession on cadavers inside a vehicle environment". Forensic Science, Medicine, and Pathology 4(1): 22-32.

[17]. Vitta A, Pumidonming W, Tangchaisuriya U, Poodendean C, Nateeworanart S (2007) "A preliminary study on insects associated with pig (Sus scrofa) carcasses in Phitsanulok, northern Thailand". Tropical Biomedicine 24(2): $1-5$.

[18]. Campobasso CP, Falamingo R, Grattagliano I, Vinci F (2009) The mummified corpse in a domestic setting. The American Journal of Forensic Medicine and Pathology 30(3): 307-310.

[19]. Campobasso CP, Di Vella G, \& Introna F (2001) "Factors affecting decomposition and Diptera colonization". Forensic Science International 120(1): 18-27.

[20]. Amos TG (1968) "Some laboratory observations on the rates of development, mortality and oviposition of Dermestes frischii (Kug.)(Col., Dermestidae)". Journal of Stored Products Research 4(2): 103-117.

[21]. Woodroffe GE, Coombs CW (1979) "The development of several species of Dermestes (Coleoptera: Dermestidae) on various vegetable foodstuffs". Journal of Stored Products Research 15(3): 95-100. 